\title{
Main Determinants of Foreign Direct Investment in the Southeast European Countries
}

\author{
Valerija Botrić ${ }^{1}$ and Lorena Škuflić ${ }^{2}$ \\ ${ }^{1}$ Institute of Economics, Zagreb, Croatia \\ ${ }^{2}$ Graduate School of Economics and Business, University of Zagreb, \\ Zagreb, Croatia \\ (E-mail: vbotric@eizg.hr, lskuflic@efzg.hr)
}

\begin{abstract}
The growth of foreign direct investments (FDI) in the world has been significant in recent years. Between 1990 and 2000 worldwide FDI inflows increased more than five times, and since 2000 they have declined. During the period of FDI expansion, growth was especially strong from 1997 onward. However, most of the FDI transactions were between the developed countries. The distribution of FDI is unequal and less-developing countries face difficulties in attracting FDI. Despite the fact that FDI is increasingly important to developing countries, over the past few years the share of the developing countries in worldwide FDI inflows has been declining. The paper analyses geographical and sector distribution of FDI in the Southeast European countries (SEEC) and compares its amount with that in Central East European countries. According to economic theory, FDI towards developing countries flows for labor-intensive and low-technology production, while towards developed states, it flows for high-technology production. Identification of determining factors of FDI is a complex problem which depends on several characteristics specific for each country, sectors, and companies. All those factors could be grouped in three broad categories: economic policy of host country, economic performance, and attractiveness of national economy. On the desegregated level, FDI depends on size and growth potential of a national economy, natural resources endowments and quality of workforce, openness to international trade and access to international markets, and quality of physical, financial, and technological infrastructure. An important question is how SEEC can attract more foreign investment. To find the answer, this paper uses data on FDI inflows to SEEC to determine the main host country determinants of FDI and provides regression-based estimation of determinants of FDI. Using a sample of SEEC and panel data techniques, the determinants of FDI in this part of Europe are investigated. The paper researches the relationship between FDI, GDP, GDP per capita, number of inhabitants, trade openness, inflation, external debt, and information and communication technology sectors. For SEEC, FDI inflows are largely dependent on the completion of the privatization process and in this paper we include the level of private sector and privatization as explanatory variables. Our findings suggest that certain variables such as privatization and trade regime, as well as the density of infrastructure, appear to be robust under different
\end{abstract}


specifications. A positive significance of the agglomeration factor is also observed, confirming the relevant theoretical propositions. However, certain differential variables, such as the privatization, could not be fully captured due to the statistical homogeneity of the sample.

Keywords: determinant; foreign direct investment stock; foreign direct investment inflow; Southeast European country.

JEL classification: F21, P20.

It has been argued in the literature (Bosworth and Collins 1999) that the ability to attract international capital can offer large potential benefits for developing countries. First of all, foreign capital can be used to augment domestic savings (which is usually at a low level) and thus enable countries to increase the rates of capital accumulation. Consequently, this should improve longer-term growth prospects and increase wealth of the population, in other words, speed the development process. Access to the international capital market provides the means to finance increased needs for resources in developing countries. Not only is the fresh capital relevant, so are other, more intangible assets as well. Some types of foreign capital inflows, principally foreign direct investment, facilitate the transfer of managerial and technological know-how.

After the fall of the Berlin wall and the Balkan crisis, formerly centrally planned economies underwent a transition process. In economic analyses of that period they have been usually divided into two groups, Central European countries (CEEC) and Southeast European countries (SEEC). The latter are generally less developed, receive less FDI, have weaker relationships with the European Union, and are more lagging in the speed of transition than the former. According to the statistics of the United Nations Conference on Trade and Development, CEECs include nineteen formerly centrally planned economies and cover also our sample of SEEC. ${ }^{1}$ In order to fulfill the purpose of this paper, we divide CEEC into two groups: CEEC-8 and SEEC-7, or eight present EU members and seven countries which are very different in political and development terms, economies that will become significant partners in the next enlargement round.

In this paper, we will investigate the main determinants of the FDI inflows to SEEC, with specific interest in answering the question how to increase the investments in those economies. Our research includes the following countries: Albania, Bosnia and Herzegovina, Bulgaria, Croatia, Serbia and Montenegro, and Macedonia. ${ }^{2}$

The structure of this paper is the following. In the next section, we introduce the concept of FDI and review the literature on the main determinants of FDI. Then we present trends in the FDI flows in the CEEC- 8 and SEEC-7. 
After that, we discuss the estimation methodology for determining the main determinants of the FDI and the estimation results. Finally, we draw some conclusions.

\section{What is the FDI and why is it important for developing countries?}

To explain the difference in the FDI performance among countries, it is necessary to understand how foreign investors choose their investment locations. The FDI usually goes to the countries where it is possible to combine the ownership advantages with the location-specific advantages of the host countries through internationalization advantages of foreign investments (UNCTAD 1998). ${ }^{3}$ With respect to our hypotheses, we will focus on the specific advantages of the host countries. The host country determinants of the FDI may be broadly grouped into three categories: policy framework for the FDI, economic conditions, and business facilitations.

In an economic sense, direct investments depend on different aspects of investments: the motive for investment (market-seeking, resource-seeking, and efficiency-seeking), type of investment (greenfield or brownfield), the sector of investment (manufacturing or services), and the size of multinational company or investor. However, one must also include locationspecific factors, which are more stable over the period. According to the above mentioned, the principal economic determinants of the FDI in a specific case could be different. The market-seeking FDI aims at penetrating the local markets of host countries and is usually connected with market size and per capita income, market growth, access to regional and global markets, consumer preferences, and structure of domestic market. The resource-assetseeking FDI depends on prices of raw materials, lower unit labor cost of unskilled labor force, and the pool of skilled labor, physical infrastructure (ports, roads, power, and telecommunication), and the level of technology. The efficiency-seeking FDI is motivated by creating new sources of competitiveness for firms and it goes where the costs of production are lower. In this last case, prior to decision, foreign investors consider prices of factors of production (adjusted for productivity differences) and the membership in regional integration agreement (UNCTAD 1998). Consequently, the efficiencyseeking FDI covers both previously mentioned types of the FDI. It is necessary to stress that it is not possible to distinguish exactly between firm-specific and country-specific determinants of the FDI, or to determine motives of small versus large foreign affiliates.

Casson (1990) emphasized that the theory of the FDI represents an intersection of three theories: the theory of international capital markets, which defines the financing and risk-sharing arrangements; the theory of the firm, which describes the location advantages, management and input utilization; and the trade theory, which explains the motives for sales in the world 
economy. Each theory provides different insights on the FDI flows. The determinants of the FDI are taken from those three theories.

FDI represents an important source of finance for developing countries and transition countries but unfortunately most of the FDI inflows and outflows are concentrated within the developed countries. In economic literature, there are differences between the FDI inflows to the developed countries and those to the less-developed countries (Markusen et al. 1996, Carr et al. 1998). Available data indicates that the inward and outward FDI shift jointly across time and across countries (Lipsey 2000).

The FDI inflows to less-developed countries are associated with vertical investments. The vertical FDI takes place when a firm relocates only a part of its production process but not the whole production. In many cases, it is the relocation of the labor-intensive activities in low-wage countries. This process tends to reduce the labor intensity of the home country domestic production (Mariotti et al. 2003). Vertical FDI are usually driven by differences in factor endowments and prices of the factors of production between home and host countries. Foreign investors are motivated by the differences of factors of production, like inexpensive labor, natural resources, specific skills, and infrastructure.

The FDI inflows to developed countries are usually horizontal investments driven by market-seeking strategies, and they tend to increase the labor intensity of the home country domestic production (Mariotti et al. 2003). Therefore, horizontal investments replicate the complete production process of the home country in a foreign country. The horizontal FDI seeks to take advantages of a new large market, which is considered as traditional motive for the FDI. In recent years, the determinants of and motivation for the FDI in developing countries have changed in the process of globalization.

The FDI is considered responsible for welfare increase in the host country due to advantages related to the introduction of new technologies and innovation, new managerial techniques, development of additional skills (Caves 1974, Perez 1997), increased capital, job creation and improvement of working conditions, and the development of the industrial sector in the host country (Haddad and Harrison 1993, Markusen and Venables 1999). Due to these facts, it can easily be understood why so many developing countries seek new ways to increase FDI inflows. In order to design appropriate economic policies to attract FDI, one must first find out what motivates the investors to seek other markets - in other words, what are the key determinants of the FDI.

Because the FDI is a rather complex economic category which depends on many factors whose relative importance changes as the economic environment evolves over time, it is possible that - because the economy of the host country changes as well as the international environment evolves the FDI factors also change (UNCTAD 1998). Even though traditional 
determinants and the types of the FDI associated with them have not disappeared with globalization, their importance is declining. For example, one of the most important traditional FDI determinants, the market size, has decreased in importance, while at the same time some new determinants became prominent. Cost differences between locations, the quality of infrastructure, the easiness of doing business, and the availability of skills have increased in importance (UNCTAD 1996). This reveals that the investors' motives are changing, and consequently countries must seek new ways to attract FDI.

\section{The FDI in the CEEC-8 and the SEEC-7}

Nearly two decades after the beginning of transition in formerly centrally planned economies in Europe, it is still difficult to assess whether the process itself has been successful or not. Each country has started its own transition course with a different economic potential, different history and resource endowments. Many of the countries bordering with developed European countries had very clear perspective to join the integration process. This inclination towards integration is relevant in the case of the FDI analysis. According to the economic theory, the integration process has a strong impact on FDI inflows. Theoretical assumptions have already been proven in practice. Ireland, for example, with a stable macroeconomic system, good infrastructure, and skilled labor force, experienced one of the fastest growth rates of the FDI inflows between 1983 and 1992. Judging from the Irish experience, and that of Portugal and Greece as well, we should expect that the accession of formerly centrally planned Southeastern European economies into the EU will also exert a positive impact on FDI.

Available data reveals that FDI has become more important in transition economies during the 1990s. In 1980, the FDI inward stock represented 6.6\% of the world's GDP and this percentage was increased in the following twenty years. At the beginning of the 21st century, the FDI inward stock amounted to about $22 \%$ of the world's GDP and of this the EU had the highest percentage, reaching nearly $30 \%$.

The FDI flows to the CEEC-8 as a group have increased from USD 640 million in 1990 to 31 billion in 2002. However, a sharp decline was recorded in 2003, when FDI fell to USD 21 billion. While the worldwide FDI inflows have been declining from 2000 to 2003, the FDI inflows to the CEEC-8 moved rather volatile during that period - first they recorded a decline, followed by an increase and finally another significant decline. The FDI inflows to the "accession-eight" countries varied significantly in amount between those countries. The highest amounts of FDI were attracted by Poland, Hungary, and Czech Republic. After 2000, the FDI to Poland has decreased, and both the Czech Republic and Slovakia recorded a sharp decline of FDI in 2003. On the 
other hand, it seems that Hungary managed to maintain a relatively stable growth trend. Less attractive amongst the "accession-eight" countries for foreign investors were Lithuania, Latvia, Slovenia, and Estonia. On the overall level, the eight CEEC which today are EU members showed a sharp decline of FDI flows in 2003, from USD 23 billion to 11 billion.

One of the main reasons for the decline of the FDI has been a slowdown of privatization in the analyzed countries (UNCTAD 2004). At the same time, the greenfield investments, which are usually smaller in size, could not immediately compensate the decline in the privatization-motivated FDI. Nevertheless, this is somehow contradictory to the expectations that along the path to the EU, capital movements between the countries should increase and consequently speed the integration into the Union. Even though the FDI has declined in the same period on the global level, one would expect that the integration forces would act in a way of stronger capital movements towards these countries. It remains to be seen whether these countries will, within the European Union, be successful in terms of stronger integration in the capital market.

The SEEC have received a small part of the international direct investment flows. The FDI inflows to SEEC-7 have increased from USD 408 million in 1993 to 6.7 billion in 2003. This amount equalled about $8 \%$ of the total FDI that came into the CEEC-8 in 1993. Fortunately, the percentage in 2002 was much higher, nearly $20 \%$. In 2003, the FDI attracted by the SEEC- 7 was about $60 \%$ of the total FDI inflows to the CEEC-8, due to the fact that the total FDI inflows to the SEEC have continued to increase in 2001 and 2003. This trend is reversed in comparison with the world's FDI inflow dynamics and especially with the dynamics for the CEEC-8.

The main characteristics of the FDI in the SEEC-7 are that they are relatively small and volatile but also highly concentrated in a few countries: Croatia, Bulgaria, and Romania. Since the share of FDI in the SEE countries is quite low, it can be concluded that Albania, Bosnia and Herzegovina, Macedonia, and Serbia and Montenegro have received negligible shares of the FDI in the region. Since these are the countries that are, at the same time, the least developed ones, the pattern observed at the global level - that the FDI is predominately concentrated in more developed economies - is once again repeated at the regional level.

The FDI flows to the SEEC-7 were principally encouraged by the wave of privatization of state companies and to a lesser extent greenfield investments. Those countries are usually not deemed very interesting for foreign investors because they represent a small national and regional market with weak infrastructure and with an unpredictable perspective to become EU members. Therefore, those countries cannot provide enough motives for either efficiency-seeking or market-seeking investments, and due to this fact, they have accumulated much smaller FDI stock than the CEEC-8 over the past period. In 
Table 1. FDI inward stock as a percentage of GDP in SEEC-7

\begin{tabular}{lccccccc}
\hline Country & 1980 & 1990 & 1995 & 2000 & 2001 & 2002 & 2003 \\
\hline Albania & 0.0 & 0.0 & 7.4 & 15.4 & 18.2 & 18.8 & 18.1 \\
Bosnia and & 0.0 & 0.0 & 1.0 & 7.9 & 10.1 & 13.8 & 16.4 \\
$\quad$ Herzegovina & & & & & & & \\
Bulgaria & 0.0 & 0.5 & 3.4 & 17.9 & 20.3 & 22.6 & 29.1 \\
Croatia & 0.0 & 0.0 & 2.5 & 19.3 & 24.1 & 31.6 & 49.6 \\
Romania & 0.0 & 0.0 & 2.3 & 17.5 & 19.0 & 19.4 & 23.4 \\
Serbia and & 0.0 & 0.0 & 2.7 & 15.3 & 12.8 & 12.5 & 16.2 \\
$\quad$ Montenegro & 0.0 & 0.0 & 0.8 & 11.4 & 24.8 & 24.7 & 22.1 \\
TFYR Macedonia & 0.0 & & & & & & \\
\hline
\end{tabular}

Source: UNCTAD, http://www.unctad.org/sections/dite_dir/docs/ wir_instock_gdp_en.xls

1990, the FDI stock of the SEEC-7 amounted to USD 212 million, while the CEEC-8 attracted nearly 6 billion of the FDI in the same year. The FDI stock of the Southeast European region reached USD 36 billion by the end of 2003, which represented only $21.6 \%$ of that of the CEEC-8 FDI stock (detailed data in Table A2). Among the SEEC-7, the most important receivers were Romania (nearly USD 13 billion) and Croatia (USD 11 billion), and the next was Bulgaria with USD 5 billion. If we use a relative indicator to analyze the FDI stock, the situation has been little changed. The analysis is presented in Table 1.

The SEEC have become more interesting for investors after 1995. In 2000, the highest FDI inward stocks as a percentage of GDP were recorded for Croatia (19.3\%), Bulgaria (17.9\%), and Romania (17.5\%). These three countries were the main attractors of the FDI also in 2003. The lowest level of the FDI inward stock was recorded in Serbia and Montenegro and Bosnia and Herzegovina, less than $20 \%$.

\section{FDI determinants in the SEEC-7}

A major assumption in the literature on transitional economies is that the privatization - with the change in ownership being related to foreign or domestic owners - should induce the increased investment efficiency in the region. Through increased investment activity and its efficiency, the growth rate of the economies should also increase. The role of the FDI in this context is straightforward. Foreign investment should, almost by definition, positively contribute to the increased investment efficiency, since in addition to capital, they also introduce technology and knowledge transfer. Lovrinčević et al. (2004) studied this relation for a group of 11 transition economies ${ }^{4}$ in the period of 1993-2002. Their research found no correlation between the FDI stock and the incremental capital output ratio for these countries. However, once they have controlled for the structure of the FDI, they have found that 
there is a significant relationship between the above average share of FDI in the services sector and the increased efficiency of investment. At the same time, countries with those characteristics - more FDI in services and more efficient investment - have proven to be those with a high share of the external debt in GDP.

Researchers have put considerable effort on the empirical identification of the FDI determinants. When it comes to the analysis of the FDI directed to the CEEC, the two main approaches have been survey-type studies and formal quantitative analyses. Quantitative studies of the determinants of FDI are based on a number of different models, but the gravitational approach is the most commonly used in practice.

Since we cannot differentiate the origin of the FDI in our data sample, we did not use the gravity model. Other researchers have tried to approximate the gravity model by adding a variable for the distance from Brussels. ${ }^{5}$ Although this approach would enable us to approximate the gravity model, we believe that with the short time-span we are dealing with (and presumably inadequate quality of the available dataset for the SEEC-7), there is no need to influence our results with an additional variable at this point.

The FDI determinants can be broadly grouped into two categories: marketrelated (which cover the GDP, GDP per capita, and the GDP growth rate) and trade-related - specifically, the openness variable. Besides the mentioned traditional determinants, some economists use nontraditional determinants such as human capital (Noorbakhsh et al. 2001). For our sample of countries, we have chosen from the pool of traditional and nontraditional determinants in the literature, and on the basis of the availability of relevant indicators, we have chosen the set of possible determinants of the FDI given in Table 2.

Table 2. Possible FDI determinants in SEEC-7

\begin{tabular}{lll}
\hline Variable & Type of FDI & Expected effect \\
\hline GDP & market-seeking & positive \\
GDP growth & market-seeking & positive \\
Population & market-seeking & positive \\
Labor cost & resource/asset-seeking & negative \\
ICT & resource/asset-seeking & positive \\
Openness & efficiency-seeking & positive \\
Inflation & efficiency-seeking & \\
External debt & efficiency-seeking & \\
Service sector share & & \\
Privatization & & positive \\
Financial-sector development & & positive \\
Private-sector share & & positive \\
\hline
\end{tabular}


The data sources for our variables are presented in Table A4. Here we only briefly discuss some of the variables in Table 2 and explain their expected sign.

Openness of the economy is one of the traditional variables for explaining the FDI movements. It is defined as the trade (import plus export) share of the GDP. The expected effects may differ by the type of investment regarding local market or export orientation, the host country's foreign exchange control laws, and applied capital taxation. However, for our group of countries, we expect that the openness will indicate also the level of integration of the local economy into the regional economic flows. Therefore, the openness should have positive influence on the FDI.

Investment in capital-scarce countries is expected to yield a higher return indicating an inverse relationship between the levels of GDP and the FDI. At the same time, in case of the market-seeking FDI, there could be a positive relationship between the income level and the FDI, since the investor predominate intention is to substitute for exports. Here we use the GDP growth measured by the annual growth rate as an indicator of the market growth. We expect a positive association between the GDP growth and the FDI. Another traditional variable measuring the market size is the number of inhabitants, for which we also expect a positive sign.

One of the factors affecting investor's yield is the rate of inflation. A high return promotes the FDI and consequently the growth of prices of products the investor has invested in should be positively associated with the FDI. However, very high inflation rates or volatile inflation can be judged as an impediment to the FDI, since it is a clear sign of macroeconomic instability. Therefore, the expected sign on the inflation rate is not ex ante determined.

Labor costs are represented by the wages. Since the countries in our sample are relatively less developed with small markets, we expect that one of the relevant motives for the foreign investors could be inexpensive labor. We expected initially that higher wages should reduce the inflow of FDI. However, this might not be the case if FDI is directed predominately into the service sector (as our previous analysis revealed), where wages are higher than in other sectors. Consequently, there could also be a positive relationship between FDI and wages.

The ICT variable is defined as the number of telephone lines per 100 inhabitants, or the number of Internet connections. Both of the indicators are judged as relevant proxy for infrastructure available to foreign investors. The variables could also be used as a proxy of the relationship between the FDI and technology transfer, since they might represent the preconditions for the technology transfer. We expect a positive relationship.

In different specifications, we have also used additional variables, commonly used in the analysis of economic processes in transition economies. 
Those are the variables that try to capture the effect of transitional changes that might influence overall economic activity, and the FDI as well.

In order to reveal the main determinants of the FDI in SEEC-7, we have pooled the data in our sample and used the GLS regression method. The basic equation can be expressed as follows: $F D I=\alpha+\beta X+\varepsilon$, where $X$ denotes a specific vector of explanatory variables. Since we have specified three separate equations, the set of explanatory variables varies in each case. There are more reasons why we have specified separate equations. First of all, the data quality for the countries in our sample is not deemed to be very high. Specifically, this can be claimed for the FDI, which comes from the balance of payment data. Lipsey (2000) argues that the problem with the FDI data stems from the fact that their source is balances of payments, which are usually quite frequently revised within a short period of time. Specifically in the countries that we are investigating, these issues could be pronounced for several reasons. First of all, the transition of the statistical system towards the introduction of market concepts is relatively new in these countries with many methodological changes still to be introduced in the years to come. Secondly, due to the underdeveloped financial system and regulation enforcement it could be expected that the rate of capital-movement nondeclaring could be higher than in other similar countries. Indeed, higher percentages of errors and omissions in the balance of payments in these countries in addition to the frequent updates of the data seem to confirm that this problem is present.

The second reason is that our sample is not very long. Therefore, we did not try to include all of the variables in the same equation, but rather varied them in order to allow for more degrees of freedom in every specification.

In our first specification, the dependent variable is the net FDI.

According to the results presented in Table 3, the FDI in the SEEC-7 depends on the GDP and the GDP per capita, as well as on the population. However, according to those results, it seems that market seeking might not be the main reason why investors choose to invest in those countries. Even though the GDP level turned out to be significant and positive, the coefficient value turned out to be relatively small. Therefore, the FDI in those countries could not be considered as market-seeking. This confirms the negative coefficient on population and the GDP growth rate. When one takes into consideration the fact that all of the countries in our sample are relatively small, it seems reasonable to conclude that market seeking is not a relevant motive for the FDI in the SEEC-7. Other variables in this specification did not turn out to be significant, with only one exception openness. Indeed, openness is a variable that turned out to be most robust to various specifications, always being highly significant and exerting a positive influence on FDI in the SEEC-7. 
Table 3. First specification for determinants of FDI in SEEC-7, 1996-2002, GLS regression

\begin{tabular}{ll}
\hline Variable & Estimated coefficient $^{\mathrm{a}}$ \\
\hline Constant & $-49.26(-0.29)$ \\
GDP & $0.09^{* * *}(4.94)$ \\
GDP p.c. & $-0.23^{* *}(-2.56)$ \\
Population & $-0.10^{* * *}(-3.20)$ \\
Openness & $5.43^{* * *}(3.30)$ \\
Inflation & $0.11(0.73)$ \\
External debt & $0.02(1.43)$ \\
Telephone & $2.04(0.61)$ \\
Internet & $-14.04(-0.69)$ \\
Adjusted $\mathrm{R}^{2}$ & 0.66 \\
Nr. of observations & 49 \\
\hline
\end{tabular}

${ }^{a}$ Triple asterisks mark coefficients significant at a level of $1 \%$; double asterisks, at a level of $5 \%$. In parentheses, $t$-values are given

In order to shed some light on our results, we have tried to determine other variables which might be more significant in explaining the FDI determinants in the SEEC-7. The results are presented in Table 4.

In line with previous research, we find a positive impact of openness on the FDI, a fact that suggests that economies in which trade is important also

Table 4. Second specification for determinants of FDI in SEEC-7, 1996-2002, GLS regression

\begin{tabular}{ll}
\hline Variable & Estimated coefficient $^{\text {a }}$ \\
\hline Constant & $-1274.20^{* * *}(-4.28)$ \\
GDP & $0.07^{* * *}(5.37)$ \\
Population & $-0.07^{* * *}(-3.20)$ \\
Openness & $9.20^{* * *}(4.46)$ \\
External debt & $0.03^{* *}(2.47)$ \\
Private-sector share & $11.84^{* * *}(3.13)$ \\
Internet & $-45.33^{* * *}(-2.74)$ \\
Large-scale privatization & $-223.98^{* * *}(-3.21)$ \\
Unemployment & $12.31^{* *}(2.35)$ \\
Wage & $-0.56^{*}(-1.91)$ \\
Financial sector & $154.89^{*}(1.98)$ \\
Adjusted $\mathrm{R}^{2}$ & 0.84 \\
Nr. of observations & 49 \\
\hline & \\
a Triple asterisks mark coefficients significant at \\
a level of 1\%; double asterisks, at a level of 5\%; \\
single asterisks, at a level of 10\%. In parentheses, \\
t-values are given
\end{tabular}


receive a relatively higher share of the FDI (for instance, they pursue policies that are more attractive to foreign investors).

In this second specification, the GDP level is also positive and has a significant effect on the FDI. This is consistent with the fact that the horizontal FDI (i.e., FDI seeking a base to produce for the domestic market in the host country) is attracted to countries in which real income, and therefore domestic purchasing power, is relatively high.

The variables included in this specification are labor market and "transitional" indicators. When it comes to the labor market, the results indicate a positive relationship with the unemployment rate and a negative relationship with the wage level. The latter can be explained by the usual argument that FDI are attracted by the lower labor costs. However, the positive relationship between the unemployment rate and the FDI is not what the countries in questions would hope for.

"Transitional" variables, as we call them, include a set of qualitative characteristics of the economies. First of all, there is the share of the private sector in the economy. This variable captures the effect of the speed of transition. A larger share of the private sector implies that a larger share of the economy operates according to the market principles. This fact should appeal to the foreign investors since it indicates that market mechanisms are more developed. Our results indicate that this variable has a positive and significant influence on FDI.

However, privatization by itself does not guarantee a positive influence on FDI. This can be seen from the negative relationship between the FDI and large-scale privatization indicator. It seems that foreign investors might be more interested in small-scale privatization in these countries. One must also notice that during the analyzed period there have not yet been major privatizations in the countries in question. Although in the CEEC-8 larger systems have been privatized during that period, for the SEEC-7 this process still remains to be conducted, specifically in the areas such as telecommunications, which are some of the most interesting for the foreign investors.

During the 1990s, foreign involvement in the financial sector of emerging economies rose substantially. By the end of the decade, foreign-owned banks in Central and Eastern Europe accounted for an average of $70 \%$ of bank assets. Another related variable is the development of the financial system in the host country. Focarelli and Pozzolo (2001) showed that foreign banks prefer to operate in countries with a relatively developed and not too concentrated financial system. Our results indicate that a developed financial sector is important for FDI attraction. In addition to the fact that acquisitions of domestic financial institutions by foreign investors are common in the SEEC-7, investors in other sectors of the economy also tend to expect the same level of financial services as they are accustomed in their home country. 
The ICT sector is defined as manufacturing and services industries that produce equipment and software used for the capture, storage, transmission and presentation of information in electronic form. ${ }^{6}$ The ICT sector offers opportunities for developing countries not only to respond to market challenges in developed economies but also to improve their export sector and to increase FDI as a means to generate employment and trade.

According to Addison and Heshmati (2003), investment in the ICT infrastructure and skills helps to diversify economies. In doing so, they can separate from dependence on their natural-resource endowments and offset some of the locational disadvantages of landlocked and geographically remote countries. This can attract more FDI, particularly investment in nontraditional sectors. But as the availability of ICT infrastructure and skills becomes increasingly important in the decisions of foreign investors, poorer countries could fall further behind if they are unable to build this capacity. Our analysis reveals that the ICT variable (Internet connections) is significant but has a negative sign. This could be explained by the fact that the Internet as a tool has only started to be extensively used in those countries since 2000 . However, it should also be stressed that this is the opportunity for the future, and even though there is a negative relationship in case of the FDI, domestic investment activity must be located in the technologically advanced areas.

Finally, we also ran regressions with the FDI stock data. The results are presented in Table 5.

In Table 5, the estimation results are somewhat different from those in the previous two cases. First of all, the GDP level variable turned out to have a negative impact, as opposed to the positive one in the previous two cases.

Table 5. Determinants of FDI stock in SEEC-7, 1996-2002, GLS regression

\begin{tabular}{ll}
\hline Variable & Estimated coefficient $^{\mathrm{a}}$ \\
\hline Constant & $-306.37(-1.42)$ \\
GDP & $-0.01^{*}(-1.99)$ \\
Population & $0.02^{*}(1.76)$ \\
External debt & $-0.01^{* * *}(-2.71)$ \\
Service sector share & $9.51^{* *}(2.48)$ \\
Internet & $63.67^{* * *}(11.00)$ \\
Unemployment & $-6.55^{* * *}(-5.32)$ \\
Wage & $0.60^{* * *}(3.60)$ \\
GDP growth & $1.55^{* *}(2.01)$ \\
Adjusted $\mathrm{R}^{2}$ & 0.89 \\
Nr. of observations & 49 \\
\hline
\end{tabular}

${ }^{\mathrm{a}}$ Triple asterisks mark coefficients significant at a level of 1\%; double asterisks, at a level of $5 \%$; single asterisks, at a level of $10 \%$. In parentheses, $\mathrm{t}$-values are given 
Secondly, population turned out to change the sign as well, but in the opposite direction. It can be concluded, that on the basis of our results, we are getting mixed signals for the market-seeking determinants of the FDI.

Labor market indicators behaved opposite to our previous specification unemployment exerts a negative influence and wage a small but positive influence. Even though the negative relationship with unemployment could be explained by the traditional arguments - more investments are bound to reduce unemployment eventually -, there is a small issue with the positive relation of the wage and the FDI. This could be explained by the sectoral distribution of the FDI. Since the nontradable sector is a strong attractor of FDI, it could be argued that the qualification of the labor force in this sector is also one of the relevant variables. Therefore, foreign investors are willing to increase the existing nominal wage if they have relatively skilled and productive workers.

In this case, we have a positive influence of the ICT variable on the FDI stock. It seems that on the overall level the countries that were able to accumulate more FDI are at the same time those that can offer better infrastructure in comparison with their competitors.

Our results are extremely sensitive to the data quality for the countries in question. We expect that a longer time period will enable us to provide stronger results. Another consideration is what part of the FDI inflows really changes capital formation in the receiving countries. Specifically, it is common knowledge that a significant part of the FDI recorded in the balance of payment data might actually be only changes in the ownership structure of the enterprises. This, naturally, adds quite little in terms of quantitatively measured new investments in the receiving countries. It could be argued that the main effect of this type of FDI is in the dissemination of know-how and a tighter integration of the local firms into the world market. However, this type of FDI could also be considered more similar to portfolio investment, as foreign owners are free to withdraw their assets by selling their ownership to a domestically or internationally owned private or state enterprise.

The prospects for the future FDI inflows in the SEEC coming from the other countries within the region, predominately the EU members, are not straightforward. According to Blomström and Kokko (1997), who applied their analysis on the member states, as the countries advance on their way to the EU, regional agreements could lead to a reduction in the horizontal FDI which follow a tariff-jumping motive. At the same time, economic integration can generate additional vertically integrated FDI between member countries when firms are able to geographically fragment production at low costs. In any case, it seems that the SEEC will probably follow a similar path as their CEEC neighbors. Whether or not they will learn from the obstacles or repeat the same mistakes still remains to be seen. 
The latest research indicates that one of the important factors for increasing the FDI inflows is increasing the efficiency of institutions. Bénassy-Quéré et al. (2005) show that public efficiency is a major determinant of inward FDI. The public efficiency includes tax systems, easiness to create a company, absence of corruption, transparency, contract law, security of property rights, efficiency of justice, and prudential standards. These results are encouraging for our sample of countries in the sense that efforts towards raising the quality of institutions and making them converge towards those of the FDI source countries could increase the chances of catching-up. Since Bénassy-Quéré et al. (2005) found that the impact of improving institutional surroundings is large, meaning that moving from a low level to a high level of institutional quality could have as much impact as suddenly becoming a neighbor of a large source country, it could provide a path for the SEEC to improve their economic activity. Governments, therefore, have greater powers to encourage the "vertical" FDI. Aside from a supportive policy framework, the human capital stock heavily influences the FDI flows and the associated technology transfer.

\section{Conclusions}

We have analyzed the FDI determinants in the SEEC-7 during the period of 1996-2002. We have used the GLS regression analysis on a pooled sample and tried to determine whether the traditional and less traditional determinants prove significant for our sample of countries. The analysis shows that marketseeking determinants of the FDI (GDP level, GDP per capita, GDP growth, population) give mixed signals in different specifications.

We were unable to provide definitive conclusions on the relationship between unemployment and FDI in the SEEC-7 because the results are not robust to different specifications. Therefore, at this point it cannot be concluded that the FDI will exert a positive influence on the vast labor market problems in those countries.

The only variable robust to different specifications was openness. At the same time, characteristics of the economies, such as private-sector share or service sector share, also proved to be significant and exerted a positive influence on FDI. It can be concluded that the increasing trade with other economies, and the development itself, will contribute to the stronger integration of the SEEC with other economies in the region and at the same time positively influence FDI. As on the global level, once again we can confirm that FDI is attracted by development.

One of the issues not discussed in this paper is the business climate. Relatively recent in Croatia, foreign investors have organized themselves in order to achieve common goals on the local market. In their first address to the public, they have pronounced the lack of an adequate business climate as one of the most important impediments to doing business in Croatia. Since 
this statement comprises many different factors, most of which are quite intangible, it could be argued that the most important conclusion and recommendation for the countries in our sample is to improve the business climate, reduce the administrative procedures, and increase transparency. Other indicators, including those that we have analyzed in this paper, will improve along with the more intangible ones.

\section{Appendix}

Table A1. FDI inflows (million USD) to SEEC-7, 1993-2003

\begin{tabular}{|c|c|c|c|c|c|c|c|c|c|c|c|}
\hline $\begin{array}{l}\text { Region or } \\
\text { country }\end{array}$ & 1993 & 1994 & 1995 & 1996 & 1997 & 1998 & 1999 & 2000 & 2001 & 2002 & 2003 \\
\hline CEEC-8 & 5248.10 & 4747.09 & 12194.00 & 10461.15 & 12066.38 & 16680.28 & 18564.26 & 20328.59 & 18392.59 & 22588.39 & 11459.26 \\
\hline Albania & 58.00 & 53.00 & 70.00 & 90.10 & 47.50 & 45.01 & 41.20 & 143.00 & 207.30 & 135.00 & 180.40 \\
\hline $\begin{array}{l}\text { Bosnia and } \\
\text { Herzego- } \\
\text { vina }\end{array}$ & 0.00 & 0.01 & 0.03 & -2.00 & 1.00 & 55.75 & 154.07 & 147.21 & 130.17 & 265.36 & 380.91 \\
\hline Bulgaria & 40.00 & 105.40 & 90.40 & 109.00 & 504.80 & 537.30 & 818.80 & 1001.50 & 812.90 & 904.70 & 1419.40 \\
\hline Croatia & 120.30 & 117.00 & 114.20 & 510.80 & 532.90 & 932.40 & 1467.20 & 1088.70 & 1561.30 & 1123.99 & 1712.95 \\
\hline Romania & 94.00 & 341.00 & 419.00 & 263.00 & 1215.00 & 2031.00 & 1041.00 & 1037.00 & 1157.00 & 1144.00 & 1566.00 \\
\hline $\begin{array}{c}\text { Serbia and } \\
\text { Monte- } \\
\text { negro }\end{array}$ & 96.11 & 62.58 & 44.99 & 0.00 & 740.00 & 113.00 & 112.00 & 25.00 & 165.00 & 475.00 & 1360.00 \\
\hline $\begin{array}{l}\text { TFYR Mac- } \\
\text { edonia }\end{array}$ & 0.01 & 24.00 & 9.49 & 11.21 & 30.09 & 127.73 & 32.70 & 174.53 & 441.53 & 77.82 & 94.56 \\
\hline $\begin{array}{l}\text { Total } \\
\text { SEEC-7 }\end{array}$ & 408.42 & 702.99 & 748.11 & 982.11 & 3071.29 & 3842.19 & 3666.97 & 3616.94 & 4475.20 & 4125.87 & 6714.22 \\
\hline $\begin{array}{l}\text { SEEC-7 to } \\
\text { CEEC-8 } \\
\text { (\%) }\end{array}$ & 7.8 & 14.8 & 6.1 & 9.4 & 25.5 & 23.0 & 19.8 & 17.8 & 24.3 & 18.3 & 58.6 \\
\hline
\end{tabular}

Source: UNCTAD, http://www.unctad.org/sections/dite_dir/docs/wir_inflows_en.xls

Table A2. FDI inflow per capita (USD) in SEEC-7, 1995-2003

\begin{tabular}{lccccccccc}
\hline Country or region & 1995 & 1996 & 1997 & 1998 & 1999 & 2000 & 2001 & 2002 & 2003 \\
\hline Albania & 21 & 27 & 14 & 13 & 12 & 47 & 67 & 45 & 57 \\
Bosnia and & & & & 18 & 47 & 39 & 31 & 69 & 99 \\
$\quad$ Herzegovina & & & & & & & & & \\
Bulgaria & 11 & 13 & 61 & 65 & 100 & 123 & 103 & 115 & 181 \\
Croatia & 24 & 114 & 117 & 207 & 322 & 245 & 352 & 253 & 440 \\
Romania & 18 & 12 & 54 & 90 & 46 & 46 & 52 & 52 & 72 \\
$\quad$ Serbia and & & & 70 & 11 & 13 & 6 & 20 & 57 & 152 \\
$\quad$ Montenegro & & & & & & & & & \\
TFYR & 5 & 6 & 15 & 64 & 16 & 86 & 217 & 38 & 46 \\
$\quad$ Macedonia & & & & & & & & & \\
Total SEEC-7 & 14.1 & 18.5 & 57.8 & 72.3 & 69.0 & 68.0 & 84.2 & 77.6 & 126.3 \\
$\quad$ Czech Republic & 248 & 138 & 126 & 361 & 615 & 485 & 552 & 832 & 253 \\
Hungary & 459 & 319 & 405 & 326 & 323 & 272 & 388 & 282 & 249 \\
\hline
\end{tabular}

Source: Hunya, 2004 and authors' calculation 


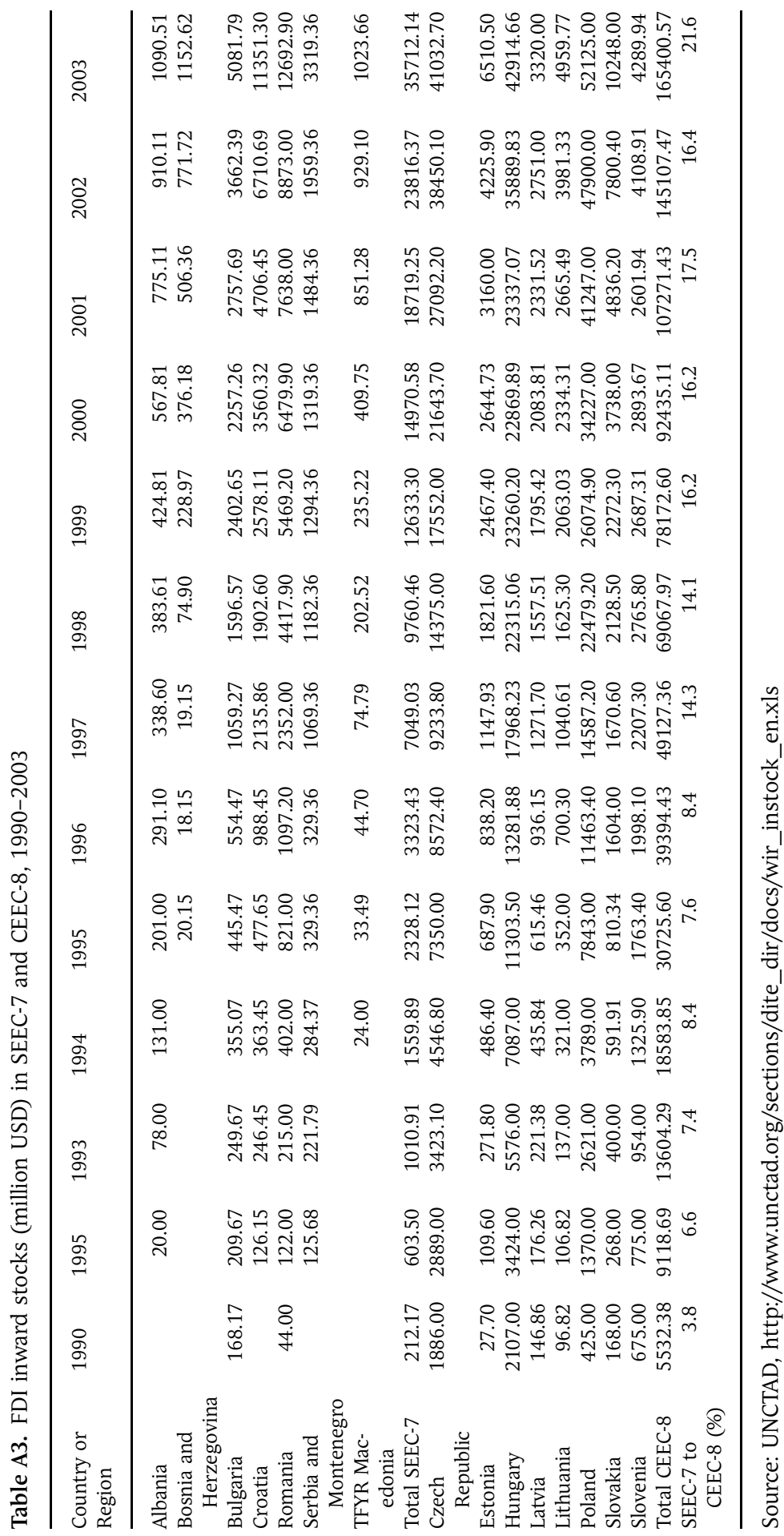


Table A4. Data sources

\begin{tabular}{|c|c|c|}
\hline Variable & Part(s) of sample & Source \\
\hline FDI & whole sample & $\begin{array}{l}\text { UNCTAD, Key Data from WIR Annex } \\
\text { Tables, http://www.unctad.org/ }\end{array}$ \\
\hline GDP & whole sample & $\begin{array}{l}\text { WDI, World Bank, } \\
\text { http://devdata.worldbank.org/data-query/ }\end{array}$ \\
\hline GDP p.c. & whole sample & $\begin{array}{l}\text { Own calculation based on WDI data, } \\
\text { World Bank, } \\
\text { http://devdata.worldbank.org/data-query/ }\end{array}$ \\
\hline Population & whole sample & $\begin{array}{l}\text { WDI, World Bank, } \\
\text { http://devdata.worldbank.org/data-query/ }\end{array}$ \\
\hline Openness & whole sample & $\begin{array}{l}\text { Own calculation based on WDI, World } \\
\text { Bank, } \\
\text { http://devdata.worldbank.org/data-query/ }\end{array}$ \\
\hline External debt & whole sample & $\begin{array}{l}\text { WDI, World Bank, } \\
\text { http://devdata.worldbank.org/data-query/ }\end{array}$ \\
\hline \multirow[t]{3}{*}{ Wage } & $\begin{array}{l}\text { Bulgaria, Croatia, FYR Macedonia, } \\
\text { Romania, Serbia and Montenegro }\end{array}$ & $\begin{array}{l}\text { WIIW Handbook of Statistics, various } \\
\text { issues }\end{array}$ \\
\hline & Albania & Institute of Statistics, Albania \\
\hline & Bosnia and Herzegovina & Statistics BIH, Central Bank \\
\hline \multirow[t]{3}{*}{ Unemployment } & $\begin{array}{l}\text { Bulgaria, Croatia, FYR Macedonia, } \\
\text { Romania, Serbia and Montenegro }\end{array}$ & $\begin{array}{l}\text { WIIW Handbook of Statistics, various } \\
\text { issues }\end{array}$ \\
\hline & Albania & Institute of Statistics, Albania \\
\hline & Bosnia and Herzegovina & Statistics BIH, Central Bank \\
\hline $\begin{array}{l}\text { Share of services } \\
\text { sector }\end{array}$ & whole sample & $\begin{array}{l}\text { WDI, World Bank, } \\
\text { http://devdata.worldbank.org/data-query/ }\end{array}$ \\
\hline $\begin{array}{l}\text { Share of private } \\
\text { sector }\end{array}$ & whole sample & Transition Report, EBRD, various issues \\
\hline $\begin{array}{l}\text { Privatization, } \\
\text { large scale }\end{array}$ & whole sample & Transition Report, EBRD, various issues \\
\hline Financial sector & whole sample & Transition Report, EBRD, various issues \\
\hline Telephone & whole sample & $\begin{array}{l}\text { UNCTAD, Statistical Databases, } \\
\text { Millennium Indicator Database }\end{array}$ \\
\hline Internet & whole sample & $\begin{array}{l}\text { UNCTAD, Statistical Databases, } \\
\text { Millennium Indicator Database }\end{array}$ \\
\hline
\end{tabular}

\section{Notes}

1 CEE countries by UNCTAD are Albania, Belarus, Bosnia and Herzegovina, Bulgaria, Croatia, Czech Republic, Estonia, Hungary, Latvia, Lithuania, Moldova, Poland, Romania, Russian Federation, Serbia and Montenegro, Slovakia, Slovenia, TFYR Macedonia, Ukraine.

2 Most of the countries are small or medium sized. The only exception is Romania with 22 million inhabitants. The region is diverse in political and also economic conditions terms. On the one side is Romania with a GDP of USD 54198 million, while on the other side is Macedonia with a GDP of USD 4639 million, in 2003. As we compare GDP per capita, the most developed country amongst SEEC-7 is Croatia with a GDP per capita greater than USD 6000, while the poorest is Bosnia and Herzegovina with less than USD 2000.

3 Dunning (1993) stressed that FDI takes place when three sets of factors exist simultaneously: ownership-specific advantage, location-specific advantage, and exploiting both advantages through internationalization.

4 Bulgaria, Czech Republic, Estonia, Latvia, Lithuania, Hungary, Poland, Romania, Slovakia, and Slovenia.

5 See, for example, Campos and Kinoshita (2003), who study the CEEC. 
6 The ICT sector includes computer and telecommunications equipment; industrial process equipment; consumer electronic goods; dedicated software services; instrumentation and packaged software.

\section{References}

Addison T, Heshmati A (2003) The new global determinants of FDI flows to developing countries the importance of ICT and democratization. Discussion Paper 2003/45. World Institute for Development Economics Research, United Nations University, Helsinki

Bénassy-Quéré A, Coupet M, Mayer T (2005) Institutional determinants of foreign direct investment. Working Paper 2005-05. Centre d'Etudes Prospectives et d'Information Internationales, Paris

Blomström M, Kokko A (1997) Regional integration and foreign direct investment. NBER Working Paper 6019. National Bureau of Economic Research, Cambridge, Mass

Bosworth B, Collins SM (1999) Capital flows to developing economies: implications for saving and investment. Brookings Papers on Economic Activity 1999(1): 143-169

Campos FN, Kinoshita F (2003) Why does FDI go where it goes? New evidence from the transition economies. Working Paper 228. International Monetary Fund, Washington, DC

Carr DL, Markusen JR, Maskus KE (1998) Estimating the knowledge capital model of the multinational enterprise. Working Paper 6773. National Bureau of Economic Research, Cambridge, Mass

Casson M (1990) The theory of foreign direct investment. In: Buckley P (ed) International investment. Edward Elgar, Aldershot

Caves RE (1974) Multinational firms, competition and productivity in host-country markets. Economica 32: 176-193

Dunning JH (1993) Multinational enterprises and the global economy. Addison-Wesley, New York

Focarelli D, Pozzolo AF (2001) The patterns of cross-border bank mergers and shareholdings in OECD countries. Journal of Banking and Finance 25: 2305-2337

Haddad M, Harrison A (1993) Are there positive spillovers from direct foreign investment? Journal of Developing Economics 42: 51-74

Hunya G (2004) Foreign direct investment in South East Europe in 2003-2004. Vienna Instiute of International Economic Research, Vienna

Lipsey RE (2000) Interpreting developed countries' foreign direct investment. Working Paper 7810. National Bureau of Economic Reseach, Cambridge, Mass

Lovrinčević Ž, Marić Z, Mikulić D (2004) Efikasnost investicija i FDI - stara priča, nove okolnosti. In: Teodorović I (ed) Hrvatska na putu u Europsku Uniju. Ekonomski Institut, Zagreb, pp 52-89

Mariotti S, Mutinelli M, Piscitello L (2003) Home country employment and foreign direct investment: evidence from the Italian case. Cambridge Journal of Economics 27: 419-431

Markusen JR, Venables AJ (1999) Foreign direct investment as a catalyst for industrial development. European Economic Review 43: 335-356

Markusen JR, Venables AJ, Konan DE, Zhang KH (1996) A unified treatment of horizontal direct investment, vertical direct investment and the pattern of trade in goods and services. Working Paper 5696. National Bureau of Economic Research, Cambridge, Mass

Noorbakhsh F, Paloni A, Youssef A (2001) Human capital and FDI inflows to developing countries: new empirical evidence. World Development 29: 1593-1610

Perez T (1997) Multinational enterprises and technological spillovers: an evolutionary model. Evolutionary Economics 7: 169-192

UNCTAD (1996) World investment report 1996: investment, trade and international policy agreements. United Nations, New York

UNCTAD (1998) World investment report 1998: trends and determinants. United Nations, New York

UNCTAD (2004) World investment report 2004: the shift towards services. United Nations, New York 